finally calcareous siliciclastics. This same pattern occurs cyclically as a vertical sequence with oil shale at the base.

The calcimicrites at the depocenter increase in dolomite content dramatically in the upper third of the section, and oil shale units become more widespread. There is an accompanying increase in saline minerals as well as zeolites indicating hypersalinity.

Bioturbation is absent from both oil shale and dolomicrites. The marginal bioturbated facies are always dominated by calcimicrite, even in the upper third of the section. Wellpreserved fossil fish occur in kerogen-rich calcimicrites, but never in dolomicrites.

The facies patterns and vertical sequences in Fossil basin are interpreted as being deposited in a closed-basin occupied by a lake with an ephemeral and hypersaline hypolimnion that underwent frequent vertical fluctuations that affected large areas of the lake bottom. The "transgression-regression" of the hypolimnion over large areas of lake bottom was possible because of a low topographic gradient on the lake bottom. Deposition of oil shale occurred within the denser, cooler, and hypersaline hypolimnion waters-laminated calcimicrite in a zone of chemocline fluctuation-and bioturbated calcimicrite was deposited in fresher nearshore zones. Kerogen-rich carbonates became more widespread in the later stages of the lake when it evolved into a shallow hypersaline lake. This suggests that kerogen deposition was controlled by high salinity rather than anoxic conditions.

It is concluded that the carbonate facies patterns, vertical sequences, and oil shale genesis required a dynamic and fluctuating lake as well as a fluctuating chemocline level in a closed basin with a low topographic gradient. This differs from the static, anoxic, and deep basin model frequently postulated for Green River Formation oil shale deposition.

BUDNIK, ROY T., Bur. Econ. Geology, Univ. Texas, Austin, TX

Recurrent Motion on Precambrian-Age Basement Faults, Palo Duro Basin, Texas Panhandle

The distribution of Late Precambrian(?) through Quaternary strata in the Palo Duro basin and surrounding uplifts documents recurrent motion on Precambrian-age basement faults. Basement blocks have been uplifted with little tilting or folding of overlying strata along a system of northwest-southeast oriented faults, part of a regional trend extending from central Colorado to southwestern Oklahoma. The orientation of basement terranes in Colorado and that of a $50-\mathrm{mi}(80-\mathrm{km})$ long mylonite zone in east-central New Mexico suggest a Precambrian age for the faults.

An Arkosic sandstone overlies basement and underlies a Cambrian(?) quartzose sandstone in a few Palo Duro basin wells. It may represent debris shed from active fault blocks during the opening of the southern Oklahoma aulocogen in the Late Precambrian or Early Cambrian. Ordovician carbonates thin or are missing beneath Mississippian carbonates on some fault blocks, indicating a post-Ordovician-pre-Mississippian period of faulting.

The greatest amount of deformation occurred during the Pennsylvanian. Thickness, distribution, and facies of sediments were controlled by the location of active faults. Lower Pennsylvanian strata thin by up to $50 \%$ across some structures. Fault blocks provided sources of arkosic debris and loci for carbonate buildups throughout the Pennsylvanian and Early Permian. Around the periphery of the basin, Late Pennsylvanian or Early Permian faulting caused a wedging out of older units beneath the Wolfcamp.
Permian, Triassic, and Neogene units, along with present topography, all have been subtly affected by basement structures. The entire section thins over basement highs. Middle and Upper Permian evaporites are thicker in structural lows. The overlying Dockum Group (Triassic) and Ogallala Formation (Neogene), both nonmarine clastic units, become finer grained over basement highs. Present topographic highs coincide with some basement highs. Also, in some places remarkably straight stream segments parallel basement faults. Low-level seismic activity, primarily north and west of the Palo Duro basin, suggests continuing motion on at least some of the faults.

BUFFLER, RICHARD T., STANLEY D. LOCKER, CLINT D. CAGLE, WILLIAM B. SAWYER, JOHN C. CROWE, and RONALD L. PHAIR, Univ. Texas, Inst. Geophysics, Austin, $\mathrm{TX}$

\section{Results of Ocean Margin Drilling Program Synthesis of Gulf of} Mexico Basin

A series of 23 maps plus three cross sections synthesize and integrate for the first time geologic and geophysical data from both the deep central Gulf of Mexico basin and the periphery of the basin. These maps and sections are part of the Ocean Margin Drilling Program synthesis of the Gulf of Mexico basin, a joint project sponsored by the National Science Foundation/Joint Oceanographic Institutions, Inc., and a consortium of petroleum companies. The study area is bounded by $30^{\circ} / 31^{\circ}$ on the north, $98^{\circ}$ on the west, $82^{\circ}$ on the east, and $18^{\circ}$ on the south (excluding Cuba and the Yucatan basin). Maps include a regional tectonic map; a map of all seismic refraction data; six structure maps (basement, top Jurassic, top Early Cretaceous, top Late Cretaceous, top Paleogene, and top Neogene); six lithofacies maps (Oxfordian [Late Jurassic], Aptian-Cenomanian [Early Cretaceous], Coniacian-Santonian [Lake Cretaceous], Early Eocene, Miocene, and Pleistocene); and nine isopach maps (total sediment, pre-top Early Cretaceous, post-top Early Cretaceous, Late Jurassic, Early Cretaceous, Lake Cretaceous, Paleogene, Neogene, and Pleistocene). Also included are two N-S cross sections and one E-W cross section. This project is an attempt to synthesize all data available in the public domain. Data for the deep central Gulf are based mainly on regional multifold seismic lines, while data from the periphery are based mainly on the published literature. These maps and sections present for the first time an integrated and comprehensive look at the structure and stratigraphy of the entire central Gulf basin as well as document many details of the early history and later filling of the basin.

BULLEN, SUSAN B., Amoco Production Co., Houston, TX, and DUNCAN F. SIBLEY, Michigan State Univ., East Lansing, MI

\section{Dolomite Selectivity, An Experimental Approach}

Hydrothermal dolomitization of corals, gastropods, pelecypods, echinoderms, forams, and coralline algae indicates that grain size is more important than mineralogy in determining (1) whether or not a fossil will be dolomitized and (2) whether or not the dolomite will pseudomorphically replace a fossil.

Dolomite commonly selectively replaces matrix and/or specific fossils. When dolomite replaces fossils, certain fossils retain their optical characteristics (i.e., pseudomorphic replacement). These selective characteristics have been attributed to both grain size and mineralogy and have been used to make inferences about the predolomitization diagenetic history of sediments. 